The Philosophical Journal of Conflict and Violence

Vol. II, Issue 2/2018

(C) The Authors 2018

Available online at http://trivent-publishing.eu/

\title{
The Concealment of Violence in the History of Fencing: Semantics, Codification, and Deterritorialization
}

\author{
Elise Defrasne Ait-Said
}

Cognition and Action Group (UMR 8257, Université Paris-Descartes), France

\begin{abstract}
Depending on historical periods and individual perspectives, fencing has been defined in various ways. Indeed, fencing has been regarded as an art, and/or a science, and/or a sport, and/or a game. This paper shows that those various attempts to define fencing throughout history are strategies aiming to conceal the founding violence of fencing (although these strategies do not prevent the emergence of further forms of violence). The study demonstrates that these strategies pertain to semantics, to regulation and codification of fencing, and to more recent phenomena which are linked to the deterritorialization of the practice of fencing.
\end{abstract}

Keywords: Jules Barbey d'Aurevilly; Gilles Deleuze; Roger Caillois; Deterritorialization; Duelling; Fencing; Game; History; Sport; Violence.

\section{TRIVENT}

The PJCV Journal is published by Trivent Publishing.

This is an Open Access article distributed in accordance with the Creative Commons Attribution Non Commercial (CC-BY-NC-ND 4.0) license, which permits others to copy or share the article, provided original work is properly cited and that this is not done for commercial purposes. Users may not remix, transform, or build upon the material and may not distribute the modified material (http:/ / creativecommons.org/ licenses/by-nc/4.0/) 


\title{
The Concealment of Violence in the History of Fencing: Semantics, Codification, and Deterritorialization
}

\author{
Elise Defrasne Ait-Said \\ Cognition and Action Group \\ (UMR 8257, Université Paris-Descartes), France
}

\begin{abstract}
Depending on historical periods and individual perspectives, fencing has been defined in various ways. Indeed, fencing has been regarded as an art, and/or a science, and/or a sport, and/or a game. This paper shows that those various attempts to define fencing throughout history are strategies aiming to conceal the founding violence of fencing (although these strategies do not prevent the emergence of further forms of violence). The study demonstrates that these strategies pertain to semantics, to regulation and codification of fencing, and to more recent phenomena which are linked to the deterritorialization of the practice of fencing.
\end{abstract}

Keywords: Jules Barbey d'Aurevilly; Gilles Deleuze; Roger Caillois; Deterritorialization; Duelling; Fencing; Game; History; Sport; Violence.

\section{Introduction}

"Mon club. Le jeu se passe ici" ["My club. The game takes place here."] was the slogan of a promotional poster issued by the French Federation of Fencing (Fédération Francaise $d^{\prime}$ Escrime) in june 20181. The poster shows a very young, diligent and focused foil fencer who is "En garde" in accordance with the most academic postures. In the picture's background, on can see an armory in cold colors. The colorful sneakers of the child are the only fancy detail of the poster. For a careful observer, this promotional poster raises some questions. First, why is this austere, almost rigorist, picture used to promote a game? For, as shown by Caillois, games necessarily involve recreation and relaxation. However, perhaps the poster refers to the concept of serious games which is popular among contemporary specialists of educational sciences. Does the poster represent fencing as a serious game that combines the diligence and high standards inherent to the proficiency at a specific activity with the pleasures of recreation? Eventually, and more generally, the promotional poster of the Fédération Française d'Escrime raises questions regarding the links between fencing and games. These links appear as obvious on the poster but are actually more complex.

It is true that one may find in professional fencing numerous aspects that are inherent to the concept of game as defined by Caillois. A game is a free activity which is delimited within a specific time and space frame. It is an uncertain and unproductive activity which can either be codified or fictional (these two latter aspects are more or less mutually exclusive). The idea that fencing belongs to the game-category is clearly mentioned by Caillois:

\footnotetext{
1 The poster can be downloaded via the following link: http://www.escrime-ffe.fr/communication/campagne-de-rentree (accessed December 3, 2018).
} 
An outcome known in advance, with no possibility of error or surprise, clearly leading to an inescapable result, is incompatible with the nature of play. Constant and unpredictable definitions of the situation are necessary, such as are produced by each attack or counterattack in fencing or football, in each return of the tennis ball, or in chess, each time one of the players moves a piece. The game consists of the need to find or continue at once a response which is free within the limits set by the rules. ${ }^{2}$

According to Caillois, the sport of fencing combines the features of agôn with those of mimicry. Fencing is a simulated competition. It is a competition, or it pertains to agôn. In other words, fencing is:

like a combat in which equality of chances is artificially created, in order that the adversaries should confront each other under ideal conditions, susceptible of giving precise and incontestable value to the winner's triumph. ${ }^{3}$

But fencing also entails the features of simulacra and mimicry:

For nonparticipants, every agôn is a spectacle... Great sports events are nevertheless special occasions for mimicry, but it must be recalled that the simulation is now transferred from the participants to the audience. It is not the athletes who mimic, but the spectators. [...] In a word, these are dramas whose vicissitudes keep the public breathless, and lead to denouements which exalt some and depress others. ${ }^{4}$

\section{Is there a Genuine Continuity between Fencing and Past Practices of Duelling?}

Caillois establishes a clear distinction between fencing and dueling. He regards the latter as not belonging to the game-category or, at least, a borderline case of the game-category:

[Outside the domain of games or at its very limits], the spirit of agôn is found in other cultural phenomena conforming to the game code: in the duel, in the tournament, and in certain constant and noteworthy aspects of so-called courtly war. ${ }^{5}$

This split between fencing and dueling is also mentioned in Vigarello's studies. The process of sportivization leads to a phenomenon of "derealization", that is to say that the initial context of the practice of dueling becomes an artificial context in fencing ${ }^{6}$. In modern fencing, the weapons of war are replaced with an electronic equipment, and arbitrary rules ${ }^{7}$

\footnotetext{
2 Roger Caillois, Man, Play and Games, trans. Meyer Barash (Chicago: University of Illinois Press, 2001), 7-8.

3 Ibid., 14. Emphasis mine.

${ }^{4}$ Ibid., 22. Emphasis mine.

5 Ibid., 15.

${ }^{6}$ See Georges Vigarello, Une histoire culturelle du sport. Techniques d'hier...et d'aujourd'bui (Paris : R. Laffont et Revue EPS, 1988) \& Histoire. (Paris : Editions Carnets Nord/ Le Pommier, 2018).

7 Even the rules pertaining to the foil are based on an arbitrary codification. As noticed by Popelin: "During the $17^{\text {th }}$ century, the good fencer was the one who was able to touch the adversary without being touched. Rules and conventions were only good manners practiced in Academies. Before the emergence of fencing as a sport, realism was the sole matter. Thus, La Faugère, an excellent duelist and tough foil user, stated that it was not necessary for the attacked person to follow the rules pertaining to the parry. The essential part was to win and protect oneself." ["Au XVII ${ }^{e}$ siècle, il fallait toucher sans être touché pour être bon escrimeur et les conventions n'étaient que de bonnes manières
} 
organize the game and regulate (or codify) the movements of the participants. Hence, fencing is defined as belonging to the category of sports and games such as tennis, football or running 8 . However, shouldn't we say that fencing has some unique, or even atypical, features which differentiates it from such kind of games? Aren't they some features of the sport of fencing which bear some resemblance and continuity-especially from the perspective of violence-with past practices such as dueling?

Children who start to learn to use the foil clearly see the possible singularity of the sport of fencing. Indeed, they often ask their instructor: "If I lose the rubber piece at the tip of the blade, will the tip be peaked and sharp?" When children are equipped with a foil made of steel, they have the intuition that something might happen, and they need to ask this question and to be reassured before accepting the progression of the game with a carefree state of mind.

If the gestures of fencing are the legacy of the gestures of the dueling to death-during which the weapon was thrusted deep into the adversary's flesh-then shouldn't we conclude that there is a problematic continuity between dueling and fencing? In addition, shouldn't we ask whether modern fencing aims to conceal this conspicuous continuity? With respect to gestures, does the straight thrust as it practiced nowadays with an instructor wearing a plastron really differ from the straight thrust that was meant to kill the opponent in the duel? Admittedly, the intentions are different. But the gesture of modern fencing characterized by the perpendicular position of the blade with respect to the target (in such a way that the switch at the tip of the foil triggers the electrical mechanism ${ }^{9}$ ) is probably not that different from the gesture through which the weapon passes between the opponent's ribs and perforates his chest. The tip of the foil moves towards its target. It accelerates and aims to find a breach through the opponents' resistance. Eventually, the hand rises on impact on the target and the blow is carried by the action of the legs. Does this straight thrust, as it is taught and executed nowadays, differ from the straight thrust of our forefathers which, so many times, was leading to the opponent's death? Is the excitement prior to action, this excitement that the fencer experiences before he starts his attack, so different from the feelings experienced by fighters in the past? The fencer is on the lookout. He aims to assess the right moment and the right distance to carry out his attack. His whole being is committed to reach the target. Does his attitude really differ from that of the duelist?

Although nowadays some admire the sport of fencing for its visual qualities, it is worth reminding that the gestures of fencing were not initially conceived for aesthetic reasons. Fencing belongs to the so-called teleokinetic activities (i.e., coordinated action of muscle groups for a spatial $\mathrm{aim}^{10}$ ). As noticed by Annick Muguet, in fencing the goal is

to touch with a weapon the body of the adversary. The goal is not to prove that one has the best posture or that one performs the most beautiful technical gestures-even though the aesthetic of the gestures is linked to the efficiency of the best fencers. From a historical perspective, fencing has often been regarded as a morphokinetic activity taught for the beauty of the

en usage dans les Académies. Avant l'escrime sportive, c'était le réalisme qui prévalait. Ainsi La Faugère, excellent duelliste et fort tireur au fleuret, affirmait que rien n'oblige l'attaqué à prendre la parade, l'essentiel était de se garantir. "]. See Daniel Popelin, Escrime. Enseignement et entrainement (Paris: Amphora, 2002), 17.

8 Roger Caillois, Man, Play and Games, 14.

9 "The required pressure in order to trigger the electric power of the circuit of the foil and thus of the whole electric equipment, must be greater than 750 grams, i.e. this weight must be pushed back by the spring of the button at the tip of the foil." See Règlement pour les éprenves FIE (2017), 11.

${ }^{10}$ See Yves Kerlirzin, Gilles Dietrich, Stéphane Vieilledent, Le contrôle moteur. Organisation et Contrôle du Mouvement, (Paris : PUF, 2009). 
gesture. This deviation from the initial aims has always and more or less influenced the apprenticeship of fencing. ${ }^{11}$

The gestures and positions "à l'amble"12 of the fencer guarantee his safety during his movements. The position "mise de profil" diminishes the possibilities to be touched by the adversary, and the unarmed hand acts like a pendulum to balance the body's movements in space $^{13}$.

Practicing fencing nowadays amounts to repeat gestures which were thoroughly conceived, designed and tested in order to kill. In modern fencing, gestures remain the same, but their initial meaning and aim have been adulterated. Initially, the gestures were not meant to knock out, hurt or incapacitate the opponent-those are the aims of other combat sports such as wrestling or boxing), but meant to destroy the opponent in the most radical way. Practicing fencing today amounts to repeat and to mimic gestures that have been conceived as murderous during a period in which man did not delegate the responsibility for the opponent's death to the mechanism of the firearm. In Jusserand's words, fencing is emblematic of the "noblesse's disdain for weapons that kill from a long distance." 14 For, from the perspective of the noblesse, one must take care of the killing alone. It must be done with one's own hands. The adversary must not be kept at distance. One must get closer to him. Body and mind must be fully engaged and committed in the killing. One must muster his strengths in order to spike the opponent's body with his blade held at arm's length.

The sport of fencing is the legacy of a founding violence. This idea has been well demonstrated by historians ${ }^{15}$ and is substantiated by archives of the $16^{\text {th }}-18^{\text {th }}$ century which present the duel as a total social fact [fait social total] -in the sense that Marcel Mauss gave to this expression, that is, a biological, psychological and sociological fact which bears the signs of a specific historical period and indicates a certain way of being towards oneself and towards the other. As Billacois observes:

Due to its numerous meanings and implications, duelling is a total social fact. It is a judicial institution (or, at least, a para-institution or counterinstitution). It is a criterion that establishes social differences and prestige. It is a political phenomenon (pertaining to opposition and/or loyalism). It is a work of art which is at the same time ephemeral and of great aesthetic value. It is a religious (and/or impious) ritual. It is also, or at least it appears to be, a demographic phenomenon. ${ }^{16}$

At that time, the sword strike leading to the adversary's death was "neat" [porté "proprement»]. Only medical examiners were able to correctly identify the thin wound which was typical of people who were killed during a duel. The historical registers of the corpses stored in mortuaries sheds light on the extent of the practice of duelling ${ }^{17}$.

\footnotetext{
11 Annick Muguet, Escrime et EPS, même combat (Document CREFFAPS, 1992), 10. In morphokinetic activities, the general form or aesthetic of the body's movements are the sole aim (e.g., dancing).

12 A l'amble: the leg corresponding to the armed arm is in front. The forward or backward movements are made without crossing the feet, they start with the front leg for walking, with the rear leg for retirement.

${ }^{13}$ See Raoul Cléry, Escrime. Fleuret, épée, sabre (Paris : Editions Fédération Française d'Escrime, 1965).

${ }^{14}$ Jean-Jules Jusserand, Les sports et jeux d'exercice dans l'ancienne France (Geneva: Editions Slatkine Reprints, 1986), 14.

${ }^{15}$ See for instance Pascal Brioist, Hervé Drévillon, et Pierre Serna, Croiser le fer. Violence et culture de lépée dans la France Moderne (XVIe-XVIIIe siècle) (Ceyzérieu: Champ Vallon, 2002).

${ }^{16}$ François Billacois, Le Duel (Paris: Editions de l'EHESS, 1986), 7.

17 Pascal Brioist, Hervé Drévillon, et Pierre Serna, Croiser le fer. Violence et culture de l'épée dans la France Moderne (XVIe-XVIII siècle), 338.
} 
Hence, we should differentiate fencing from sports or games such as tennis, running or chess. It makes more sense to put fencing into the category of non-lethal activities that were initially based and built on practices with a view to kill. What other kinds of sports could belong to this category? Shooting sports, for instance, obviously belong to this category ${ }^{18}$. Some video games in which the main aim is to virtually kill human adversaries with a firearm (e.g. Silent Scope or Return to Castle Wolfenstein) also belong to this category. First person shooter video games, or other video games which entail to virtually mimic the action of killing, certainly share some peculiar features with modern fencing.

Our observations on the nature of the links between fencing and games eventually lead us to further psychological remarks regarding the psychological motives and mechanisms in those who practice fencing today. What is the significance of practicing a sport in which one constantly plays for real while killing is just an act? Is it inconsequential to enjoy or to be fascinated with a spectacle in which participants constantly play at pretending to kill each other? What are the psychological motives behind such attitudes? What fantasies are at a play? What repressed instincts are manifested through the modern practice of fencing? It might be useful to refer to Freud in order to elucidate those issues:

The element of truth behind all this, which people are so ready to disavow, is that men are not gentle creatures who want to be loved, and who at the most can defend themselves if they are attacked; they are, on the contrary, creatures among whose instinctual endowments is to be reckoned a powerful share of aggressiveness. ${ }^{19}$

It therefore makes sense that people who practice or enjoy fencing conceal or even censor/repress instincts that are unspeakable. As I will show in the remainder of this paper, the sport of fencing will conceal its violent and problematic historical legacy through various semantic strategies. Through these strategies, fencing will even advance to the status of the most valued human activities. These phenomena are due to the combined effects of agôn and mimicry which have been stressed by Caillois:

Competition and simulation may and indeed do create cultural forms to which an educational or aesthetic value is readily ascribable. Stable and influential institutions are frequently and almost inevitably derived from them. Regulated competition is in fact, equivalent to sports... ${ }^{20}$

\section{Semantic Strategies. Concealment of Violence and Emergence of new forms of violence.}

It was not enough for them to kill their man: they wanted to kill him in a learned way, artistically, in accord with the best principles of the art. Above all, they insisted on demonstrating grace and elegance in combat, and they had nothing but contempt for those rough and tough but clumsy types who were called duellists but by no means merited the term fencers. ${ }^{21}$

Fencing has been labelled as an art and/or a science, and/or a sport, and/or a game. Although these labels have different semantic values, they share an important feature insofar as they tend to conceal the violent origins of fencing. Indeed, fencing is valorized

\footnotetext{
${ }^{18}$ Eugène Chapus, Le sport à Paris en 1854 (Paris : Chistera, 2017).

19 Sigmund Freud, Civilization and its Discontents, trans. James Strachey (New York: W.W. Norton, 1961).

${ }^{20}$ Roger Caillois, Man, Play and Games, 76-77.

21 Jules Barbey D'Aurevilly, Les Diaboliques, trans. Raymond N. Mackenzie (Minneapolis: University of Minnesota Press, 2015).
} 
and rationalized when it is raised to the level of science and art. When fencing is labeled as a game (agôn-mimicry, or simulated competition), its gestures and practice are de-dramatized and normalized. When fencing is defined as a sport, it becomes a restrained and controlled violence, that is, an activity in conformity with social norms and requirements. All these semantic strategies are significant. They contribute to mold the cognitive representations of fencing and turn it into an acceptable and highly valuable activity. In each case, the bleak reality of dueling is kept at distance. However, it seems that these semantic strategies give rise to new forms of violence which are different from the violence they aimed to conceal.

\section{A. Fencing as an "art of self-defense"}

"Faire de l'escrime" ["To practice fencing"]: what are the origins of such an expression whose sound is pleasing to the ear? Scholars who are most passionate about fencing will contend that it existed since the beginning of humanity ${ }^{22}$. In other words, fencing was practiced long before men called it such. It exists since the time when men used wood and stones, then later bronze and iron, in order to make weapons to protect themselves from animals or other men ${ }^{23}$. From this perspective, fencing is somehow defined as being part of the great heritage of humanity; it is consubstantial to mankind and its survival. In the end, fencing is differentiated from more secondary and less significant human activities.

Nonetheless, the historian and the semiologist answer the question of the origins of fencing in a rather different way. They tend to situate the genesis of fencing in relation to the first written traces that highlight the founding of an organized practice, as well as its first denominations ${ }^{24}$. It is said that the word escrime (fencing) is borrowed from the former Italian word scrima which means "art of sword handling" (1409). It is also said that the word originated from the Franconian "skirmjan" which means "to defend, to protect" (or/ and from the German word schirmen - to protect). Thus, the very etymology of the word bears the trace of euphemism or, to put it otherwise, it bears the mark of a denial of violence. Fencing is defined as an art meant to protect oneself from others, to defend oneself from the threats and dangers caused by other fellow human beings. It is not defined as a way to attack others. We may therefore wonder if, since the origins of the word escrime, there is an attempt to moralize the practice of fencing by de facto referring to it as a practice meant to protect oneself from others but not meant to knowingly attack and harm them.

Historical documents of Ancient Greece mention a practice which is somehow similar to the above-mentioned definition of fencing. There are some commonalities between the idea of fencing as an "art of self-defense" and the ancient practice of hoplomachia. During antiquity, the fight with arms or hoplomachia belonged to the category of gymnastics and

22 "Of all the weapons of war and destruction, the sword gives the most accurate representation of the inhumanities that men inflicted towards their fellow human beings." ["De toutes les armes de guerre et de destruction, l'épée est celle qui offre le meilleur précis de l'bistoire de l'inbumanité de l'bomme envers l'bomme. "] See Epées et armes blanches. Epées et armes blanches (Editions PML, 1994), 8.

23 "Before using metal, man created weapons with wood and stones. One shall not underestimate the lethal power of such primitive instruments." ["Avant de travailler le métal, l'bomme a façonné des armes offensives en bois et en pierre, et il ne faudrait pas sous-estimer la puissance meurtrière d'instruments aussi primitifs."] Ibid., 8.

${ }^{24}$ It is worth noticing that "The first daggers and swords were not all meant for war. [...] The function of numerous weapons was not to wound or to kill an adversary, but to show one's wealth, social status or power. Some weapons were meant to show technical or artistic skills. Others were meant to impress and terrorize the enemy." ["Les premiers poignards et les premières épées n'étaient pas tous conçus pour un usage guerrier, loin de là. [...] Le rôle de nombreuses armes était non de blesser ou de tuer mais de manifester la richesse, le rang social, la puissance des uns, le savoir-faire technique ou artistique des autres ; ou encore de terroriser l'ennemi.'] Ibid., 8. 
corresponded to the rise of the political system of the city-state. During this period, "to defend" was the keyword. Some theories stated that every able-bodied citizen should receive a minimal training in order to defend the city. This representation of combat in Ancient Greece will later lead, during the $7^{\text {th }}$ century B.C., to the creation of the techniques and tactics of the phalanx which was also well adapted to the rise of the city-state. Although the Greeks won several notable battles against the Persians through the tactical use of attack, the phalanx - mass military formation composed of heavy infantry armed with spears and shields - was mainly meant as a defensive method. Even when the phalanx was obliged to step back and give ground to the enemy, human losses were low for the most solid formations. In the event of a damaged or broken spearhead during the battle, a spike at the rear of the spear was meant as a secondary weapon. The sword was only used as last resort, that is, when the second spike of the spear was out of use. For soldiers, fighting with a sword was a desperate move because it entailed to lose the protection of the shield wall. Exception made of Spartans, few really dared to fight the opponent this way. Admittedly, the Hellenic understanding of the armed fight shares some features with fencing defined as the "art of self-defense". However, the etymology of the word escrime directly contradicts and conceals the historic events that gave rise to the practice of fencing.

\section{B. Fencing as a "science"}

During the $16^{\text {th }}-18^{\text {th }}$ centuries, fencing was the "science of homicide" of which the great minds of this historical era tried to theorize the main principles and laws ${ }^{25}$. These theoretical efforts did not only give rise to the publication of pedagogic treatises. Taken as an object of scientific inquiry, fencing attracted a considerable and unprecedented intellectual attention. Architects, mathematicians, engineers, and philosophers aimed to conceptualize fencing. For instance, the remarkable study on fencing of Camillo Agrippa, Trattato di Scienza d'Arme (1553), combined the precision of mathematics to artistic creativity. Of course, those writings were reserved for the social and intellectual elite. During this period, books were expensive and people able to read were scarce. Thus, the science of fencing entails a form of exclusion - the violence of social class differences-regarding people who could not afford books and/or were unable to comprehend the complex codes and theories of fencing.

The maitre d'armes (fencing master) is the guardian figure of the complex knowledge of fencing. Maitre d'armes is an atypical profession which originated during the $16^{\text {th }}$ century and whose organization was based on arm corporations or guilds. Having a solid knowledge regarding the techniques of homicide, the maittre d'armes were blamed for all evils. In 1715, the Abbé de Saint-Pierre advocates a series of measures that, according to him, must be taken in order to stop the dramatic consequences of single combats ${ }^{26}$. He suggests getting rid of the profession of maitre d'armes and recommends gentilshommes to wear a stitched coat of arms on their clothes in order to distinguish them from others. The guardian figure of the maitre d'armes did not really disappear over time and is, still nowadays, criticized for his "conservative" pedagogical methods. "The master gives the lesson; the student takes the lesson": this sentence is still representative of the relation between instructor and student in fencing nowadays. This sentence also illustrates a recurrent didactic context which is emblematic of fencing: lessons are only given individually (i.e. a kind of "private lesson") by a fencing master in a sport club. The pedagogical confrontation of the student to the fencing master is entirely supervised, if not to say controlled, by the latter. This context entails

\footnotetext{
${ }^{25}$ See Pascal Brioist, Hervé Drévillon, \& Pierre Serna, Croiser le fer. Violence et culture de l'épée dans la France Moderne (XVIe-XVIII siècle), 129.

${ }^{26}$ Abbé de Saint-Pierre, Mémoire pour perfectionner la police contre les duels (s.l. :1715).
} 
an asymmetrical relation in which the one who knows and believes to know is clearly dominant and teaches his knowledge-of a science that has often been regarded as "esoteric"27—to a passive subject. "This highly fragmented apprenticeship in which gestures are often taught independently of their context-gestures whose reasons and utility therefore become hard to understand-lead to regrettable consequences such as constant dissents or even violence." 28 . In addition, this pedagogic context tends to favor specific fencers, identified by the master as being the more promising students. The others, neglected and more and more left out of the group, will often abandon their fencing lessons. The science of fencing therefore leads to the control and domination of the master over the student-i.e. it leads to a symbolic violence. It also leads to a form of elitism which tends to exclude those who do not promptly attract the master's attention and consideration. Therefore, some fencers have the feeling to be mocked or despised. Some develop feelings of resentment. Although the violence experienced by apprentice fencers is not physical, it is certainly not insignificant. Eventually, the scientific perspective sometimes over-intellectualizes the practice of fencing and, as a result, undermines or neutralizes the combative instinct ${ }^{29}$. Some specialists argued that those intellectual attitudes are outdated and that they no longer correspond to the reality of fencing combats. For instance, the national fencing trainer C. Martin stated in 1991 that:

The major problem of French fencers is that they favor technique at the expense of more practical matters. This problem is even more conspicuous when French fencers are confronting Cuban fencers. Cubans first aim to touch the adversary and only assess the result later. We, the French, are functioning differently: we do some gesture, and we hope that it will lead to a touch... we think too much about the technical gestures that can be done... But the guys in front of us do not ask themselves such questions. ${ }^{30}$

Questions pertaining to the efficiency of fencing, the meaning of its teaching and the relations of power between the instructor and the apprentice are certainly not new. In Ancient Greece, the utility of boplomachia was sometimes called into question. Indeed, hoplomachia has sometimes been compared with the practices of the sophists. In Plato's Eutbydemus, Socrates mocks Euthydemus and his brother Dionysodorus. The two brothers are sophists and are trained in weapon use. They are equally skillful in rhetoric and martial arts and gave teachings in both domains in exchange for money. In Plato's Laches, combat with weapons is presented as a new phenomenon, as a kind of sport technique, or gymnastic, which does not necessarily entail superior combat skills. In the same dialogue, Nicias describes hoplomachia as a beautiful science which prepares to the learning and practice of the science of tactics. Laches, on the contrary, argues that the teaching and practice of hoplomachia is useless with respect to the necessary skills of the hoplites and to the efficiency of warfare methods. Hoplomachia appears as a vain knowledge:

\footnotetext{
${ }^{27}$ Daniel Popelin, Escrime. Enseignement et Entrainement, 22.

28 ["L'apprentissage, en miettes, de gestes extraits de leur contexte, dont on comprend plus ou moins bien les raisons et l'utilité, conduit à des dérives regrettables, comme la contestation systématique, voire la violence. "] Ibid., 19.

${ }^{29}$ See the statement of P. Omnès (olympic fencing champion in 1992): "In France, we need a lot of time to discover talents and champions. In our country, fencing is a sport for "old people". French fencing is very technical, and learning requires a lot of time. It is a little bit the same situation in Russia, whereas Italian fencing is more instinctive..." ["Chez nous les champions sont tardifs, l'escrime est un sport de «vieux ». L'escrime française est très technique, elle demande du temps pour être assimilée, un peu comme en Russie, alors qu'en Italie, c'est plus instinctif... "]. L'Equipe (April 9, 1998).

${ }^{30}$ Escrime Magazine, 29 (June-July 1991).
} 
Then again, Lysimachus, I've met quite a few of these fellows in the work itself, and I see what they are. Indeed, we can look at it from that point of view: for as though to illustrate the point, not one of these experts in armorfighting has ever yet become distinguished in war. And yet those who get a name for anything else do so from the practice of it. It seems these folk, compared to others, have in this respect been quite remarkably unfortunate. For instance, take this fellow Stesilaus, whom you and I watched putting on a show in that great crowd and boasting about himself. I watched him elsewhere under real conditions put on a better show-though not voluntarily. ${ }^{31}$

\section{Fencing as a "Game"}

Let us now turn to the modern efforts towards the simplification of the teaching and practice of fencing. Fencing masters and specialists in physical education have defended the pedagogical advantages of teaching fencing at school ${ }^{32}$. This gave rise to a new way of proselytizing evidenced by the increasing popularity of the keywords fencing-gamepedagogy on the world wide web.

Redefined as a game, fencing implies a series of pedagogical situations in which the apprentice is implicitly and immediately invited to experience the logic of the game and expected to (more or less spontaneously) figure out and do the relevant gestures (for instance, learning to touch the adversary with his weapon or to be touched by the adversary's weapon without being scared). In addition, the game of fencing is taught during collective lessons. For instance, in the "hut game" ("jeu de la cabane"), the play zone is divided into a central fencing area and "huts" in which each young fencer is said to be "invulnerable" 33 . The aim of this ludic apparatus is at the same time to respect beginners" usual apprehensions and to encourage them to touch the adversary with their foil. In this specific context, environment is understood in terms of Gibson's concept of affordance ${ }^{34}$.

Furthermore, beginners in fencing can use weapons made of composite material instead of using the traditional weapons made of steel. From the perspective of the history of technology, changes in weapon design frequently lead to changes regarding the forms and collective representations of combat. Such changes may occur in modern fencing. Indeed, fencing may be gradually taught and practiced outside the traditional hall of arms. The Maitre d'armes may lose their monopoly on the instruction of fencing which may be more and more granted to physical education teachers ${ }^{35}$.

In any case, it seems that the technological and pedagogical innovations of modern fencing tend to mitigate some forms of violence that we previously mentioned. Given that the practice of fencing tends to become accessible to all (due to its more affordable sport equipment and to its simplified pedagogy), the violence of social class differences. In addition, the monopoly of the maitres d'armes on the teaching of fencing is significantly weakened. Collective lessons ensure fairer relations between the instructor and each

${ }^{31}$ Plato, The Dialogues of Plato Volume 3, trans. R. E. Allen (New Haven: Yale University Press, 1996), 65.

32 See Daniel Popelin, Escrime. Enseignement et Entraînement; Annick Muguet, Escrime et EPS, même combat; Jean-Pierre Philippon, Escrime à l'école primaire. Documentation pédagogique à l'usage des enseignants (Fédération Française d'Escrime, 2008).

33 Annick Muguet, Escrime et EPS, même combat, 34.

${ }^{34}$ James J. Gibson, The Ecological Approach to Visual Perception (Boston: Houghton Mifflin Harcourt, 1979).

${ }^{35}$ See for instance Jean-Pierre Philippon, Escrime à l'école primaire. Documentation pédagogique à l'usage des enseignants. 
member of the group; this new pedagogic framework mitigates symbolic violence. Eventually, common representations regarding fencing change due to the use of new weapons made of composite material. Obviously, the weapon made of plastic seems less formidable than the weapon made of steel ${ }^{36}$. These changes lead to a more mixed practice of fencing in which girls are not put aside; they tend to mitigate the violence of gender inequality. However, as we shall see, fencing as a "game" is not an entirely non-violent activity. Pedagogic games normalize and de-dramatize the practice of fencing. In other words, the game's paradigm reduces the alertness and vigilance that apprentices should normally have with respect to fencing. It might therefore create favorable conditions for the emergence of more insidious forms of violence that may emerge in rather unpredictable ways...

I would like to highlight the fact that the use of the game concept with respect to fencing is a strategy which is certainly not historically unprecedented. From a historical perspective, we may even say that the evolution of fencing and the evolution of the concept of "game" are deeply intertwined. Habits and customs evolve through time and change our most common understandings of pleasures and entertainment ${ }^{37}$. After the Hellenic period of defensive fencing, Ancient Rome turned fencing into a violent spectacle. The Roman ludi included gladiator fights ${ }^{38}$ in which opponents were not wearing the same type of arms. This asymmetry between fighters was supposed to force gladiators to express their adroitness and craftiness and, by the same token, to entertain and astonish the audience. For example, the equipment of the retiarius was a weighted net, a three-pointed trident, and a dagger. The retiarius did not wear any head protection. Initially, the retiarius was fighting against the murmillo who was heavily armed with a big shield (scutum), a sword (gladius), and a large helmet with a crest (cassis crista). But it turned out that it was too easy for the retiarius to hook up the crest of the murmillo's helmet to his weighted net. As a result, the potential length of the gladiator fights risked being reduced and the audience risked being less and less entertained by the spectacle. Hence, starting from mid-1 ${ }^{\text {st }}$ century, gladiator fights were organized differently; the retiarius would fight against the secutor or, less frequently, against the scissor.

One cannot separate the history of fencing from the history of weapons. Weapons and their features always entail specific combat practices. During Roman games, spectators were watching gladiators crushing the adversary's bones, destroying his arms and legs, dismembering him, smashing his skull, destroying his face, thrusting the sword deep into his flesh. The pleasures linked to fencing were obviously the pleasures of watching orchestrated and showy massacres. In this society of the spectacle, people did not try to conceal their taste for blood. People were aware of their enjoyment to watch gladiator fights. It has been said that some men of power did not hesitate to personally and publicly take part at the fights. Some historical sources state that the Roman emperor Commodus went several times down to the arena to fight against gladiators or wild beasts. Games, pleasure, risk and death were deeply interconnected ${ }^{39}$. Galen, the physician to the gladiators, observed major brain and spinal cord injuries in fighters which were the terrible consequences of these Dantesque battles. It is through these personal experiences that Galen advanced scientific

\footnotetext{
${ }^{36}$ Regarding the common representations of fencing in beginners see Annick Muguet, Escrime et EPS, même combat, 30.

${ }^{37}$ Elisabeth Belmas, Jouer autrefois. Essai sur le jeu dans la France moderne. XVI ${ }^{e}-X V I I I{ }^{e}$ siècle (Champ Vallon, 2006).

${ }^{38}$ Eric Teyssier, La mort en face. Le dossier gladiateurs (Arles: Actes Sud, 2009).

39 Regarding the eroticization of gladiator fights, see David-De Palacio, "Gladiateur, " in Dictionnaire de la violence, ed. Michela Marzano (Paris : PUF, 2011), 542.
} 
knowledge about the human brain. Later in history, gladiator fights will be banned and regarded as acts of debauchery.

Many centuries later, writers will sometimes describe the game of fencing in a rather ironic way. For instance, during the $17^{\text {th }}$ century, in Molière's theatre play Le Bourgeois Gentilhomme. The character of the fencing master explains to Mister Jourdain:

As I have told you, the entire secret of fencing lies in two things: to give and not to receive; and as I demonstrated to you the other day, it is impossible for you to receive, if you know how to turn your opponent's sword from the line of your body. This depends solely on a slight movement of the wrist, either inward or outward. ${ }^{40}$

This quote obviously shows an oversimplification of the techniques and principles of fencing. In a comical way, Molière depreciates an activity that was often regarded, at his time, as a most serious matter. He mocks an activity that was commonly regarded as noble by presenting it as a mere game. In Molière's play, fencing is a game in its most trivial sense, that is to say, an activity that even the most simple-minded person can achieve and understand. Some engravings from the $17^{\text {th }}$ century which represent an overview of the "joys and pleasures of childhood" ("les joies et plaisirs de l'enfant") also show the prominent place of fencing as game. For instance, an engraving represents two naked kids who joyfully fight each other with wooden swords. However, a warning message written at the bottom of the engraving indicates that, contrary to other games for children (such blind man's bluff), fencing must be practiced with caution ${ }^{41}$. Children can pretend to fight with their fake weapons but they must not hit and hurt each other. In other words, there is only a thin line between the game and the real drama. The game of fencing requires participants to demonstrate constant concentration and vigilance in order to prevent the always dangerous consequences of some gestures (for, as we saw, the gestures of fencing were initially meant to be dangerous).

In other words, the deadly effects of the gestures of the duellists may occur in the game of fencing in rather unpredictable ways. Lethal gestures can emerge independently of the participants' intentions. Nowadays, the violent origins of fencing sometimes suddenly come back and remind their existence to participants who believe that fencing is just a game. Hence, despite the numerous measures taken to prevent violence, there is still a very latent and insidious violence in modern fencing. Those considerations are substantiated by some dramatic events during the $20^{\text {th }}$ century. In 1960 , N.A. is a young man who works as a radar technician for the air force. While he builds the scale model of a plane, his roomate is standing behind him and playing with a small fencing foil. N.A. does not notice his roommate's action and when he turns his chair towards him, he accidently receives a foil shot in the right nostril that penetrates into his left anterior brain. N.A. survived this accident but, since then, he suffers from deep anterograde amnesia. A further accident happened in 1982 during the world championship of fencing at Rome. During his fight against the soviet fencing champion Smirnov, the German fencer Behr touches his adversary with his foil. At the moment of impact of the foil on Smirnov's chest, the blade

40 Molière, The Middle Class Gentleman, trans. Philip Dwight Jones (Project Gutenberg, 2008), https://www.gutenberg.org/files/2992/2992-h/2992-h.htm (accessed November 11, 2018).

41 "Bien que l'un semble plus adret a s'escrimer de son fleuret, il ne scauroit, quoy qu'il exerce, n'ayant pourpoint ny hoqueton, luy doner de quarte ou de tierce droit dans le neuviesme bouton. " Claudine Bouzonnet-Stella et Jacques Stella, Les jeux et plaisirs de l'enfance, 1667. 
breaks and goes through Smirnov's eye orbit and into his brain ${ }^{42}$. Nine days later, the soviet fencer dies. In 1985, the French fencer Philippe Conscience gets wounded by a sword at the groin during the Barcelona world championships. Conscience survived this accident which raised serious questions and concerns in the world of fencing. Could the game of fencing be lethal? This issue and people's doubts regarding the safety of fencers are still current - as show, for example, by a recent paper entitled "Olympic Games of Rio 2016: does protective equipment really protect fencers?" 43 . In any case, following the aforementioned accidents, new measures will be taken regarding the safety of professional fencers (i.e., kevlar-based protective gear, new materials for the conception of weapons and masks, systematic assessment and verification of the equipments by specialized teams). Fencing is a rather paradoxical game which needs to practiced very cautiously.

\section{Fencing as "a sport"}

The process of "derealization" of fencing combat leads to a sport-show ${ }^{44}$ in which violence is controlled 45 . It is in fencing that French athletes received the more Olympic games medals. French is the international fencing language for referees. However, France has difficulties to enroll new professional fencers and to make the training of their apprentices viable and durable ${ }^{46}$. Are these issues due to common representations according to which fencing is a practice reserved for a kind of aristocracy ${ }^{47}$ ? In any case, those difficulties constrained French fencing to diversify its modes of practice and, by the same token, to change its identity. Consequently, scholars now introduce new definitions of modern fencing such as:

Fencing is a set of codified activities which involve the use of pointed and edged weapons. These activities can be practiced alone, or within a group of two persons or more. They can be practiced in contexts of combat or cooperation. They can be practiced in order to appeal to an audience, to win, to educate, to fight and/or to mimic a fight. ${ }^{48}$

Nowadays, audiences often do not recognize the physical efforts and involvement of participants in professional fencing. For a lot of people, it is difficult to regard the fights as something genuine or real. The process of sportivization explains, at least in part, the current devaluation of fencing. In Vigarello's words, the emergence of electrical equipment in fencing leads to a "derealization of combat" rattling of swords become rarer. Nowadays, the game is more based on the subtle, precise,

\footnotetext{
${ }^{42}$ For a study regarding the reception and impact of Smirnov's accident, see Thierry Terret \& Cécile Ottogalli-Mazzacavallo, "L'effet Smirnov en question ? Perception et impact des accidents fatals en escrime," International Review on Sport \& Violence 4 (2011): 13-28.

43 Antoine Mignan, "JO de Rio 2016 : une combinaison d'escrime protège-t-elle vraiment ?, " Europe 1 (August 3, 2016), https://www.europe1.fr/sport/jo-de-rio-2016-une-combinaison-descrime-proteget-elle-vraiment-2810362 (accessed November 15, 2018).

${ }^{44}$ See Georges Vigarello, Du jeu ancien au show sportif.

${ }^{45}$ Norbert Elias \& Eric Dunning, Quest for Excitement: Sport and Leisure in the Civilizing Process (Dublin: University College of Dublin Press, 2009).

46 Daniel Popelin, Escrime. Enseignement et Entrainement, 16.

47 Annick Muguet, Escrime et EPS, même combat.

48 "L'escrime est un ensemble de pratiques codifiées utilisant des armes de pointe et de tranchant, pouvant se pratiquer seul, à deux ou en groupe, en situation d'opposition ou de coopération, dans le but de plaire ou de gagner, d'éduquer, de combattre ou/ et de mimer un combat." Cécile Ottogalli, Gérard Six, et Thierry Terret, L'bistoire de l'escrime. 1913-2013, un siècle de Fédération internationale d'escrime (Paris : Editions Atlantica, 2013), 7.

${ }^{49}$ Georges Vigarello, Une bistoire culturelle du sport. Techniques d'bier...et d'anjourd'bui.
} 
and tactical assessment of the distances that separate the two fencers. For, as stated by Vigarello:

Fencing, regardless of the weapons it involves, is above all a game based on the notion of distance. The sword, the weapon of the duel, implies that the one who touches any part of the adversary's body first will score the point. The control and assessment of distance therefore become pivotal..$^{50}$

Distance is a very subtle notion which can only be correctly assessed by the expert eye of the fencer or the connoisseur. Only the expert eye can see and comprehend the reality of the fight. In addition, the various rules used by referees for the point scoring are often regarded as very complex by non-specialized audiences. The image of sophisticated sportsmen wearing pure white jackets is clearly at odds with the audiences' taste for more entertaining spectacles and activities. Due to its controlled violence, the modern sport of fencing is therefore the subject of a more or less general indifference or disdain.

\section{Violence and Eroticism. The Semantics of the Foil.}

During its first stages, the process of sportivization of fencing induces a further kind of violence: the violence of gender discrimination. In literature, some women are described as experts in foil handling. The attitude of writers towards them is clearly ambivalent. On the one hand, female fencers are fascinating and extremely desirable. On the other hand, they are described as diabolical characters. In the context of a highly organized patriarchal society, women who know how to handle weapons are rare and are regarded as a threat to the established order. Fencing was commonly perceived as a "religion", a sacred activity which automatically glorified the men who practiced it. Popelin notices that master fencers "feel as being part of an almost apostolic mission ..., their profession is a vocation, a priesthood." 51 . Weapons were the privilege of men. In a male-controlled society, women who knew how to handle swords did not benefit from any kind of glorification. This stigmatization is perhaps part of a broader social tendency that tends to exclude women who do not comply with the catholic norms of their time ${ }^{52}$.

From a historical point of view, handling the sword is typically a male habitus. However, during the $17^{\text {th }}$ Century, the invention of the foil (fleuret) seems to create favourable conditions for a female practice of fencing. The foil is a light weapon whose usability seems to be perfectly adapted to women. Fleuret is a euphonious name for a weapon meant to the study of fencing (l'étude de l'escrime). This new weapon will lead to several changes and accentuate the euphemization of the violence of fencing. For instance, the fight between fencers will be called the phrase d'armes ${ }^{53}$ (i.e., the entire series of offensive, defensive, and counter-attack actions during combat) and therefore linked to the art of conversation. Dissonant and erotic connotations will gradually permeate the semantics of fencing. During the same period, the presence of female characters in works of fiction dealing with fencing is a rather striking coincidence. Female fencers appear in novels precisely at the period when rather ambivalent and erotic overtones are linked to the foil, and when fights are somehow compared to courteous conversations (phrase d'armes).

\footnotetext{
${ }^{50}$ Rémy Delhomme, Jean-François Di Martino, et Frédéric Carre, L'esprit de l'épée. Une approche tactique et mentale (Paris : Amphora, 2016), 22. Emphasis mine.

${ }^{51}$ Daniel Popelin, Escrime. Enseignement et Entrainement, 16. See also Jean Lesieux, Les maîtres d'armes, ces curés (Editions Aguado, 1965).

${ }^{52}$ See Guy Bechtel, Les quatre femmes de Dieu : La putain, la sorcière, la sainte et Bécassine (Paris: Plon, 2000).

${ }^{53}$ Literal translation: "phrase of weapons". However, the phrase d'armes is more commonly called Conversation in the English-speaking world.
} 
At this period, one can notice conspicuous changes regarding the vocabulary of fencing. Pivotal phases and gestures of the combat are called le froissement (friction), l'enveloppement (enfolding), l'invite (the invitation), le toucher (touching), le doigté (fingering), le liement (binding), le corps à corps (which refers at the same time to hand to hand combat and, implicitly, to lovemaking). Such a technical vocabulary is far more sensuous than the real gestures of fencing. We can even go as far as to say that it is hard to recognize the reality of the sword combat in this vocabulary. Furthermore, those new semantics conceal the most concrete goal of the duel, that is, the final foil strike. There is an obvious dissonance in the new technical vocabulary of fencing; words do not really correspond to the actual actions:

Froissement (the sudden, prolonged and powerful friction of the sword sliding towards the bottom of the opponent's blade); Enveloppement (taking the opponent's blade into a line and holding it there by completing a full circular motion); Invite (the action of voluntary offering a line of attack to the opponent); Toucher (action to hit or cut the opponent by reaching him with the tip of the blade); Doigté (ability to control the finger pressure on the grip in order to swiftly handle the foil); Liement (take the opponent's blade from high line to low line or vice versa; Corps à corps (any kind of contact between the bodies of the two fencers). ${ }^{54}$

However, those semantic dissonances are not merely artificial. Mastering fencing is not something that can be improvised. It does not suffice to make efforts or to perform energic movements. Neither does it suffice to master gentle and subtle gestures. The fencer must skillfully combine force and finesse. In the words of traditional fencing masters, he must have the sentiment $d u$ fer (i.e., the most intimate knowledge of his blade). Eventually, despite their ambiguities, semantics nonetheless reflect real and practical aspects of fencing.

Erotism and dissonance in the semantics of fencing did not go unnoticed by French novelists. In Barbey d'Aurevilly's short novel "Happiness in Crime", Mademoiselle Hauteclaire Stassin is a fencing master who fascinates men. She is a scandalous and mysterious character, an attractive and devilish woman entirely dedicated to the practice of fencing and expert in the handling of weapons. Mademoiselle Hauteclaire Stassin is an adulterous woman with murderous plans. As an object of male fantasies, she represents the eroticism and ambivalence of the new semantics of fencing:

It was the clicking sound of fencing swords crossing, rubbing, and rattling together... "Well! I said to myself, admiring the power that tastes and habits have over us. 'This must be their way of making love! '...Hauteclaire was dressed, if you could call it that, as I had so often seen her when she gave her lessons in $\mathrm{V}^{* * *}$, in a tight leather jacket that served as a cuirass, and her legs in skintight silk hose revealed their muscular contours. Savigny was wearing a similar costume... Well try to add to the magnificence of this couple by imagining how they looked to me then, standing on that balcony in those tight closes suggestive of nudity. ${ }^{55}$

Due to her status of a woman expert in handling weapons, Hauteclaire Stassin arouses men's curiosity:

His school was closed for a few days, and then Mademoiselle Hauteclaire Stassin reopened it, announcing that she would continue giving lessons as her father had; and far from loosing students after his death, she actually gained more. Men are all the same. They dislike strangeness among

\footnotetext{
54 See Manuel de l'Educateur (Fédération Française d'Escrime, 2003 [1985]).

55 Jules Barbey D’Aurevilly, Les Diaboliques, trans. Raymond N. Mackensie (Minneapolis: University of Minnesota Press, 2015).
} 
themselves and even find it painful; but if strangeness wears skirts, they are delighted with it. ${ }^{56}$

Aurevilly portrays her as half woman, half beast. Indeed, Hauteclaire Stassin is compared to the panther which she stares in the eyes at the Jardins des Plantes. A rare species from the island of Java where

... the flowers have more scent, the fruits greater savor, the beasts greater beauty and power than anywhere else on earth, and nothing can give a better idea of the violence of life in that both enchanting and poisonous country than saying it is like a combination of Armida and Locusta! ${ }^{57}$

She is a secretive and deceptive woman (a vice that Aurevilly describes as typically feminine) In a nutshell, Hauteclaire Stassin is an evil woman who has satanic designs:

And underneath all that she had a beauty marked by reserve, a nobility in her cast-down eyes, which proves that these shedevils can do anything they like with their bodies, these female snakes, when they have anything they want, no matter...At $\mathrm{V}^{* * *}$, when she was giving her fencing lessons, the men privately called her Mademoiselle Esau... The Devil teaches women their true nature-or, rather, they teach them to the Devil, if by chance he doesn't know already. ${ }^{58}$

There is a further point I would like to address. The use of the foil introduces a new age of fencing in which words will somehow take precedence over gestures. Indeed, it does not suffice to touch the opponent with his weapon. In order to score the point, one must also regard la convention (i.e., the rules of sword and fencing combat that determines the priority and legitimacy of the touches between two opponents). New specific codifications regarding combat appeared concomitantly with the advent of the foil ${ }^{59}$. From that period on, the fight will be structured on a logic of actions that fencers are bound to respect and which ultimately correspond to the phrase d'armes. It is the referee, as a third party, who will decide whether points will be granted or not. The referee observes and analyzes the entire sequence of movements and will eventually state aloud the phrase d'armes (or the Conversation). Deciding among the two participants will not solely depend on the touches but will also be based on the consideration of the very logic of the combat with foils. One shall not abruptly interrupt the words of a person who starts a conversation because the requirements of courtesy and politeness are to let him finish his speech before introducing one's own thoughts. In a similar vein, fencers cannot interrupt their opponent's actions whenever and however they wish; they must comply with a predetermined logic of actions which they initially agreed upon. Hence, the combat is indeed somehow analogous to a polite dialogue. La convention can be summarized as follows: the fencer who starts the attack (by extending his sword arm), gets the priority for scoring the touch. In order to get priority, the opponent must parry this first attack. Only then can he initiate the attack to score his touch. Of course, his adversary may parry the attack and counter-riposte. The fencing encounter continues with alternating offensive and defensive actions (attacks, parry, ripostes) until one of the two fencers touches his opponent.

\footnotetext{
56 Ibid.

${ }^{57}$ Ibid.

58 Ibid.

59 See Cécile Ottogalli, Gérard Six, et Thierry Terret, L’histoire de l'escrime. 1913-2013, un siècle de Fédération internationale d'escrime.
} 
Furthermore, the fencer can only target with his foil the torso of his opponent. Due to this reduction of the valid surface for touches, it sometimes occurs than none of the opponents scored points. Whatever the energic sequence of movements between the two fencers, off target touches will not be validated as points by the referee. After an off-target touch, the referee asks fencers to return to their en garde position and stand still for a short moment before the fight starts again. All those changes linked to the use of the foil lead to very cautious and precise attitudes in modern professional fencers. These refined and meticulous behaviors are very different from the paroxysmal features of swordfights in the past. Now that new and complex rules apply to combat sport, the game of fencing more or less tends to belong to a safe zone in which acts of hostility or unpredictable violence are normally prevented.

\section{Conclusion: A Phenomenon of Deterritorialization}

In The Seven Samurai, the characters are caught up in an urgent situationthey have accepted to defend the village-and from the beginning of the film to the end, a more profound question gnaws away at them. The question is formulated by the leader of the samurai as they leave: "What is a samurai? What is a samurai, not in general, but at his time?" Someone who no longer serves a purpose. The rulers do not need them, and the peasants will soon learn to defend themselves. Throughout the film, despite the urgency of the situation, the samurai are haunted by this question, one worthy of the Idiot: we samurai, what are we?60

Nowadays, despite the numerous efforts of master fencers, sword blades are getting rusty. Rust always comes back, and its orange-red-brown color is reminiscent of that of blood. One can notice a desire for something else in the world of fencing—or, in Deleuze's words, a desire for a new assemblage (agencement). The French Fencing Federation is quite right when it states that "Fencing is a game" which has a gloomy, sometimes sordid, historical past. In the Abécédaire, Deleuze said that "The creation of a concept always aims to answer a problem; this creation is a matter of necessity." ${ }^{1} 1$ Are we going through a barren period of fencing? Scholarly research on fencing gets more and more rare. The maitre d'armes are rather isolated from the rest of society and remain very secretive. We might have entered a period of intellectual decay which, according to birds of ill omen, will eventually sound the death knell for fencing. However, we should not judge the current situation of fencing too hastily. As Deleuze said: "Judging is the profession of many people, and it is not a good profession, but it is also the use to which many people put writing. Better to be a roadsweeper than a judge." 62

Today, new assemblages are needed in order to arouse a new desire for fencing. I have in mind assemblages that may create favorable conditions for a phenomenon of deterritorialization. We need to replace the common arguments regarding honor, rigor, discipline and respectability, i.e., the appeal to "the tradition of fencing" with other ideas which are to discover or to invent. New assemblages must be created and tried. However, we need to keep in mind the possible risk of trivializing fencing-of turning it into a dull and mannered activity - in the name of its modernization.

Since the dawn of time, fencing always reinvented itself and its modes of practice. History shows that fencing was constantly able to adapt to major societal changes. The

${ }^{60}$ Gilles Deleuze, Two Regimes of Madness, trans. Ames Hodges \& Mike Taormina (New York: Semiotext(e), 2007), 318.

${ }^{61}$ Gilles Deleuze \& Claire Parnet, L'Abécédaire -DVD (Paris : Editions Montparnasse, 2004).

${ }_{62}$ Gilles Deleuze \& Claire Parnet, Dialogues II (New York : Columbia University Press, 2007), 8. 
history of fencing went through the end of ancient Greece, the fall of the Roman Empire, the decline of knights and duelists. Fencing will adapt again; its new identity will take shape soon. We may speculate that, in the near future, fencers will confront holograms equipped with lightsabers ${ }^{63}$. It is conspicuous that the desires of our contemporaries are directed towards a novel and adventurous era of digital and virtual fencing ${ }^{64}$. Fencing of the future will probably be a dematerialized form of fencing - that is, fencing as incredibly enjoyable game devoid of any sentiment $d u$ fer. In any case, it is likely that, once again, fencing will entail new dangers.

\section{References}

D’Aurevilly, Jules Barbey. Les Diaboliques. Translated by Raymond N. Mackensie. Minneapolis : University of Minnesota Press, 2015.

Bechtel, Guy. Les quatre femmes de Dieu : La putain, la sorcière, la sainte et Bécassine. Paris : Plon, 2000.

Belmas, Elisabeth. Jouer autrefois. Essai sur le jeu dans la France moderne (XVI ${ }^{e}$-XVIII ${ }^{e}$ siècle). Champ Vallon, 2006.

Billacois, François. Le duel dans la société française des XVIe-XVIIe siècles. Essai de psychosociologie historique. Paris : Editions de l'EHESS, 1986.

Brioist, Pascal, Drévillon, Hervé, \& Serna, Pierre. Croiser le fer. Violence et culture de l'épée dans la France Moderne (XVIe-XVIIIe siècle). Ceyzérieu : Champ Vallon, 2002.

Caillois, Roger. Man, Play and Games. Translated by Meyer Barash. Chicago: University of Illinois Press, 2001.

Chapus, Eugène. Le sport à Paris en 1854. Paris : Chistera, 2017.

Cléry, Raoul. Escrime. Fleuret, épée, sabre. Paris: Editions Fédération Française d'Escrime, 1965.

Deleuze, Gilles. Two Regimes of Madness. Translated by Ames Hodges \& Mike Taormina. New York: Semiotext(e), 2007.

Deleuze, Gilles, Claire, Parnet. L'Abécédaire -DVD. Paris : Editions Montparnasse, 2004. Dialogues II. New York: Columbia University Press, 2007.

Donald, North, Anthony, Richardson, Thom, Spring, Christopher, Wilkinson, Frederick. Epées et armes blanches. Editions PML, 1994 [1989].

Elias, Norbert \& Dunning, Eric. Quest for Excitement: Sport and Leisure in the Civilizing Process. Dublin: University College of Dublin Press, 2009.

Freud, Sigmund. Civilization and its Discontents. Translated by James Strachey. New York: W.W. Norton, 1961.

Gibson, James J. The Ecological Approach to Visual Perception. Boston : Houghton Mifflin Harcourt, 1979.

Jusserand, Jean-Jules. Les sports et jeux d'exercice dans l'ancienne France. Geneva: Editions Slatkine Reprints, 1986.

Kerlirzin, Yves, Gilles Dietrich, Stéphane Vieilledent. Le contrôle moteur. Organisation et Contrôle du Mouvement. Paris : PUF, 2009.

\footnotetext{
${ }^{63}$ See the recent advertisements of the French Federation of Fencing that introduce the Académie du Sabre Laser (Lightsword Academy) which is, of course, reminiscent of Star Wars : http://www.escrime-ffe.fr/communication/campagne-de-rentree (accessed December 3, 2018).

${ }^{64} \mathrm{It}$ is worth noting that the French Federation of Fencing created the first fencing video game. See here : https://fr.play.mob.org/game/fie_swordplay.html (accessed December 3, 2018).
} 
Mignan, Antoine. «JO de Rio 2016 : une combinaison d'escrime protège-t-elle vraiment ?» Europe 1 (August 3, 2016). https://www.europe1.fr/sport/jo-de-rio-2016-une-

combinaison-descrime-protege-t-elle-vraiment-2810362 (accessed November 15, 2018).

Molière. The Middle Class Gentleman. Translated by Philip Dwight Jones. Project Gutenberg, 2008. https://www.gutenberg.org/files/2992/2992-h/2992-h.htm (accessed November 11, 2018).

Muguet, Annick. Escrime et EPS, même combat. Document CREFFAPS, 1992.

Ottogalli, Cécile, Gérard Six et Thierry Terret. L'bistoire de l'escrime. 1913-2013, un siècle de Fédération internationale d'escrime. Paris : Editions Atlantica, 2013.

Philippon, Jean-Pierre. Escrime à l'école primaire. Documentation pédagogique à l'usage des enseignants. Fédération Française d'Escrime, 2008.

Plato, The Dialogues of Plato Volume 3. Translated by R. E. Allen. New Haven: Yale University Press, 1996.

Popelin, Daniel. Escrime. Enseignement et entraînement. Paris : Amphora, 2002.

Terret, Thierry \& Ottogalli-Mazzacavallo, Cécile. «L'effet Smirnov en question ? Perception et impact des accidents fatals en escrime. » International Review on Sport \& Violence 4

(2011): 13-28.

Teyssier, Éric. La mort en face. Le dossier gladiateurs. Arles : Actes Sud, 2009.

Vigarello, Georges. Une histoire culturelle du sport. Techniques d'hier...et d'aujourd'hui. Paris : R. Laffont et Revue EPS, 1988.

Vigarello, Georges. Du jeu ancien au show sportif. Paris : Seuil, 2002. . Histoire. Paris : Editions Carnets Nord/ Le Pommier, 2018. 